A C T A C H E M I C A S C A N D I N A V I C A 22 (1968) $2401-2414$

\title{
Heats of Formation and Conformational Energies of 1,3-Dioxane and Its Methyl Homologues
}

\author{
KALEVI PIHLAJA and SINIKKA LUOMA \\ Department of Chemistry, University of Turku, Turku, Finland
}

\begin{abstract}
Heats of formation, $\Delta H_{\mathrm{f}}^{\circ}$ (liq.), of four methyl-substituted 1,3dioxanes were determined by measuring their heats of combustion, $\Delta H_{c}^{\circ}$ (liq.), at $25.0^{\circ} \mathrm{C}$. The group increments of methyl substituents at different positions were evaluated from the determined heats of formation, and the conformational energies of axial methyl groups at different positions were estimated. Moreover, the enthalpy difference between the chair and skew-boat forms of the 1,3-dioxane ring was found to be slightly higher than that between the corresponding forms of cyclohexane.
\end{abstract}

\begin{abstract}
Very little attention has been hitherto paid to the heats of formation of 1,3-dioxane and its methyl homologues. Some combustion data for these compounds were recently presented by Pihlaja and Heikkilä,, ${ }^{1,2}$ who estimated some group increments ${ }^{1}$ and conformational energies ${ }^{2}$ in the gaseous state at $25^{\circ} \mathrm{C}$ and discussed earlier results. It was of interest to study the combustion of other methyl-substituted 1,3-dioxanes and to calculate the group increments and conformational energies of the methyl groups from the heats of formation.
\end{abstract}

\section{EXPERIMENTAL}

4,4,6-Trimethyl-1,3-dioxane was prepared by the method of Rondestvedt ${ }^{3}$ from paraformaldehyde and 2-methyl-2,4-pentanediol. Physical constants: $:^{4,5}$ b.p. $143.2^{\circ} \mathrm{C}$, $d_{4}^{20} 0.9296, n_{\mathrm{D}}{ }^{20} 1.4208 ;\left(R_{\mathrm{D}}\right)_{\text {obs. }} 30.83$ (calc. 30.90$)$. Purity $\geq 99.99 \%$.

4,6-Dimethyl-1,3-dioxane was prepared by the same method from paraformaldehyde and a mixture of the meso and DL forms of 2,4-pentanediol. The product contained two isomers of which the more volatile form had the cis and the less volatile the trans configuration., ${ }^{4}$ Physical constants:

cis-4,6-Dimethyl-1,3-dioxane: b.p. $126.6^{\circ} \mathrm{C}, d_{4}{ }^{20} 0.9331, n_{\mathrm{D}}{ }^{20}$ 1.4136; $\left(R_{\mathrm{D}}\right)_{\text {obs. }} 31.08$ (calc. 30.90). Purity $\geq 99.99 \%$.

trans-4,6-Dimethyl-1,3-dioxane: b.p. $137.0-137.2^{\circ} \mathrm{C}, d_{\mathrm{A}}{ }^{20} 0.9621, n_{\mathrm{D}}{ }^{20} 1.4186$; $\left(R_{\mathrm{D}}\right)_{\text {obs. }}$ 30.72 (calc. 30.90$)$. Purity $\geq 99.99 \%$.

2,2-Dimethyl-1,3-dioxane was prepared by the method of Böeseken and Hermans ${ }^{\circ}$ from acetone and 1,3-propanediol. Physical constants: ${ }^{5,6}$ b.p. $125.0-125.5^{\circ} \mathrm{C}, d_{4}{ }^{20}$ $0.9592, n_{D}{ }^{20} 1.4207$; $\left(R_{\mathrm{D}}\right)_{\text {obs. }} 30.69$ (calc. 30.90$)$. Purity $\geq 99.99 \%$.

Acta Chem. Scand. 22 (1968) No. 8 
Calorimetric measurements: The cyclic acetals were burned in oxygen in an adiabatic bomb calorimeter No. 1221 manufactured by Parr Instruments Co., Illinois, U.S.A. The calorimeter was equipped with No. 1101 double valve bomb and with No. 1601 standard thermometers. The internal volume of the bomb was $0.3605 \mathrm{l}$ and before each experiment $1.00 \mathrm{~g}$ of water was added in the bomb. In each combustion experiment the bomb was charged with oxygen to an initial pressure of 30 atm. at $25^{\circ} \mathrm{C}$.

The energy equivalent $e^{\circ}$ (calor) of the standard calorimeter system which contained all but the sample was determined by burning Parr standard benzoic acid pellets $\left(-\Delta E_{\mathrm{B}} / \mathrm{M}=6317.83 \pm 0.62 \mathrm{cal} / \mathrm{g}\right)$ and corrections to the standardized calibration conditions were made when necessary. "In addition recalibrations were carried out following any change (e.g. replacement of crucible) in the calorimeter system.

Most of the samples burnt were sealed in Parr gelatin capsules, but the isomeric 4,6-dimethyl-1,3-dioxanes were combusted in glass ampoules and gelatin capsules in order to compare the results (Table 2). Owing to the hygroscopic nature of gelatin the weighing and filling of the capsules was carried out as soon as possible and similarly in every case. Thus the capsules were in air not more than ten minutes. The samples were fired at $25.00 \pm 0.02^{\circ} \mathrm{C}$ using an amount of substance sufficient to bring about an increase of approximately $3.6^{\circ} \mathrm{F}\left(2^{\circ} \mathrm{C}\right)$ in the calorimeter temperature.

Only those combustions after which no carbon deposits were seen in the bomb were accepted as yielding reliable results. The water contents of the reagents were minimized by several distillations on sodium, the last distillation having taken place immediately before the combustion.

The corrections for nitric acid formation (from traces of nitrogen in the oxygen) were based on $14074 \mathrm{cal} / \mathrm{mole}$ at $25^{\circ} \mathrm{C}$ for the energy of formation of $0.1 \mathrm{~N}$ nitric acid from $\mathrm{N}_{2}, \mathrm{O}_{2}$ and water. ${ }^{8}$ The corrections for sulfuric acid formation (from the sulfur in gelatin) were based on $72000 \mathrm{cal} / \mathrm{mole}$ at $25^{\circ} \mathrm{C}$ for the energy of formation of $0.17 \mathrm{~N}$ sulfuric acid.

The corrections for the lose in weight of the igniting wire coil (initial weight ab. 16 $\mathrm{mg}$ ) were based on the value $1.4 \mathrm{cal} / \mathrm{mg}$.

The corrections for the energy of combustion of the gelatin capsules were determined from the measurements of the heat of combustion of random samples chosen from a given lot of 100 capsules. The gelatin contained $0.35 \pm 0.05 \%$ of sulfur and approximately $\mathbf{4 7 . 4} \%$ of carbon, $17.1 \%$ of nitrogen, $28.3 \%$ of oxygen and $6.9 \%$ of hydrogen. The combustion experimets with gelatin capsules are presented in Table 1 .

Table 1. The heat of combustion of the gelatin capsules.

$$
\begin{aligned}
& e^{\circ}(\text { calor })=1360.40 \pm 0.20 \mathrm{cal} /{ }^{\circ} \mathrm{F} \\
& e^{\mathrm{f}}\left(\text { cont. }=2.16 \mathrm{cal} /{ }^{\circ} \mathrm{F}\right. \\
& \Delta E \Sigma=2.79 \mathrm{cal} / \mathrm{g} \\
& -\Delta n R T=1.87 \mathrm{cal} / \mathrm{g}
\end{aligned}
$$

\begin{tabular}{|c|c|c|c|c|c|}
\hline m (g) & $\Delta t\left({ }^{\circ} \mathrm{F}\right)$ & $\Delta E_{\text {igu }}(\mathrm{cal})$ & $\Delta E_{\mathrm{dec}^{\mathrm{f}}}\left(\mathrm{HNO}_{3}\right)$ & $\Delta E_{\mathrm{dec}}^{\mathrm{f}}\left(\mathrm{H}_{2} \mathrm{SO}_{4}\right)$ & $-\Delta e_{\mathrm{b}}(\mathrm{cal} / \mathrm{g})$ \\
\hline 0.6073 & 2.040 & 11.34 & 8.65 & 4.77 & 4534.64 \\
\hline 0.6233 & 2.099 & 17.92 & 9.48 & 4.90 & 4536.57 \\
\hline 0.6228 & 2.098 & 20.02 & 9.99 & 4.89 & 4533.85 \\
\hline 0.6214 & 2.085 & 10.96 & 8.28 & 4.88 & 4532.92 \\
\hline 0.6091 & 2.045 & 9.80 & 9.88 & 4.79 & 4534.42 \\
\hline 0.6111 & 2.052 & 13.02 & 9.55 & 4.80 & 4530.41 \\
\hline
\end{tabular}

${ }^{a}$ Standard deviation of the mean. 
Calculations: To obtain the weights in vacuo $(m)$ the weights of the samples (m) in air were multiplied by the following factors based on the densities of the compounds at $20^{\circ} \mathrm{C}$ :

$\begin{array}{ll}\text { 4,4,6-trimethyl-1,3-dioxane } & 1.00116 \\ \text { cis-4,6-dimethyl-1,3-dioxane } & 1.00115 \\ \text { trans-4,6-dimethyl-1,3-dioxane } & 1.00111 \\ \text { 2,2-dimethyl-1,3-dioxane } & 1.0011\end{array}$

The heats of combustion were calculated from equation

$$
\begin{aligned}
& -\Delta E_{\mathrm{c}}^{\circ}=10^{3} \frac{\mathrm{M}}{m}\left[\left(e^{\circ}(\text { calor })+e^{\mathrm{f}}(\text { cont. })\right) \Delta t-\Delta E_{\mathrm{ign}}-\Delta E_{\mathrm{dec}}{ }^{\mathrm{f}}\left(\mathrm{HNO}_{3}\right)\right. \\
& \left.-\Delta E_{\mathrm{dec}^{\mathrm{f}}}\left(\mathrm{H}_{2} \mathrm{SO}_{4}\right)+\mathrm{m}^{\prime} \Delta e_{\mathrm{c}}{ }^{\circ}(\mathrm{gel})-\Delta E_{\Sigma}\right]
\end{aligned}
$$

where $\mathbf{M}$ is the molecular weight of the compound in question, $m$ the mass of the sample in vacuo, $e^{\circ}$ (calor) energy equivalent of the standard calorimeter system (cal $/{ }^{\circ} \mathbf{F}$ ), $e^{f}(\mathrm{cont}$.) contribution to the total energy equivalent from the contents of the bomb after combus. tion (cal/ ${ }^{\circ} \mathrm{F}$ ), ${ }^{\mathrm{B}, 9} \Delta E_{\mathrm{ign}}$ the correction due to the burnt ignition wire (cal), $\Delta E_{\mathrm{dec}}{ }^{\mathrm{f}}\left(\mathrm{HNO}_{\mathrm{s}}\right)$ the correction due to the formation of nitric acid (cal), $\Delta E_{\mathrm{dec}^{\mathrm{f}}}\left(\mathrm{H}_{2} \mathrm{SO}_{4}\right)$ the correction due to the formation of sulfuric acid (cal), $\mathrm{m}^{\prime} \Delta e_{\mathrm{c}}{ }^{\circ}(\mathrm{gel})$ the energy evolved by combus. tion of the gelatin capsule (cal), and $\triangle E \Sigma$ so-called Washburn correction (cal).,

Table 2. The combustion data of 4,6-dimethyl-1,3-dioxanes.

$$
\begin{aligned}
& e^{\circ}(\text { calor })=1360.40 \pm 0.20 \mathrm{cal} /{ }^{\circ} \mathrm{F} \\
& -\Delta e_{\mathrm{c}}^{\circ}(\mathrm{gel})=4531.01 \pm 0.84 \mathrm{cal} / \mathrm{g} \\
& t_{\mathrm{h}}=t_{\mathrm{i}}=25.00^{\circ} \mathrm{C}
\end{aligned}
$$

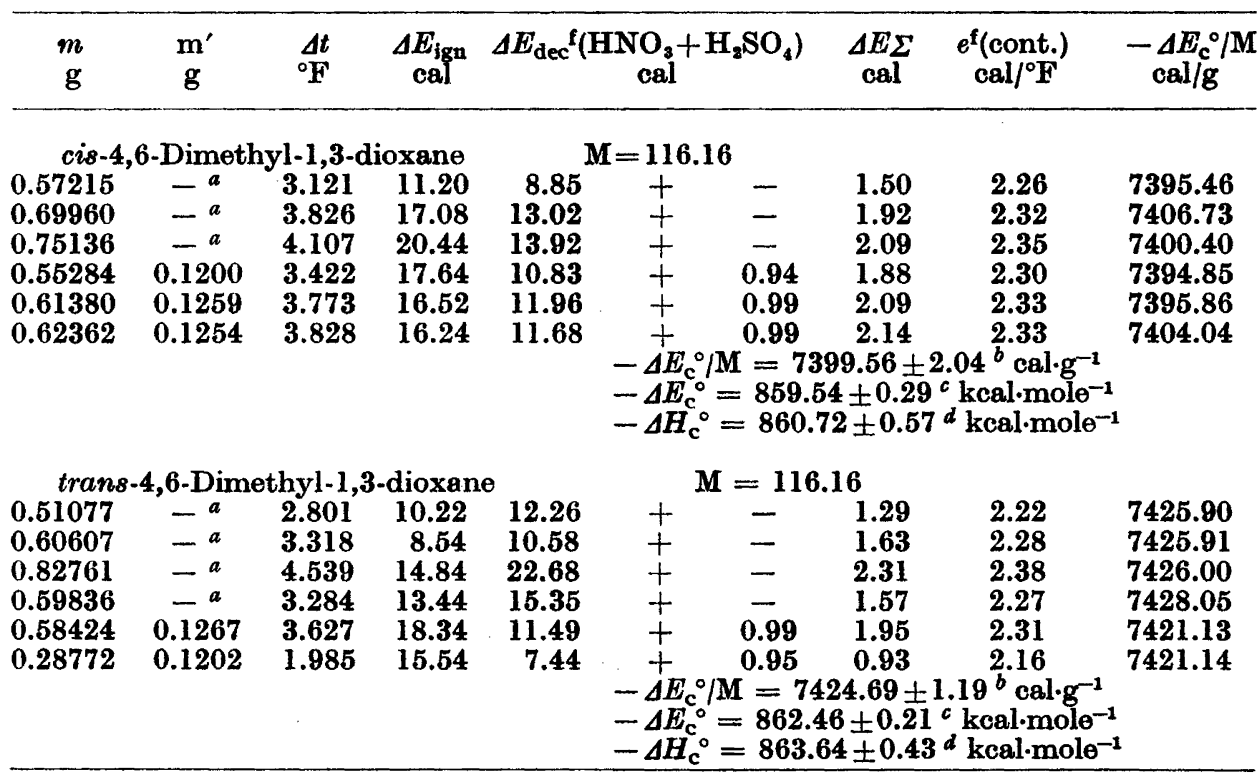

$a$ Burnt in thin soda glass ampoules. ${ }^{b}$ Standard deviation of the mean. ${ }^{c}$ Over-all standard deviation. $d$ Twice the over-all standard deviation. 
The standard heats of combustion were calculated from equation

$$
\Delta H_{\mathrm{c}}{ }^{\circ}=\Delta E_{\mathrm{c}}{ }^{\circ}+\Delta n R T
$$

where $\Delta n$ is the difference in the number of gaseous reactants and products.

The standard heats of formation, $\Delta H_{f}^{\circ}$ (liq.) were calculated from standard heats of combustion assuming the values $\Delta H_{\mathrm{f}}{ }^{\circ}\left(\mathrm{CO}_{2}, \mathrm{~g}\right)=-94.052 \mathrm{kcal} / \mathrm{mole}$ and $\Delta H_{\mathrm{f}}{ }^{\circ}\left(\mathrm{H}_{2} \mathrm{O}\right.$, liq.) $=-68.315 \mathrm{kcal} / \mathrm{mole}$ recommended by the National Bureau of Standards.

In earlier reports ${ }^{1,2}$ the conditions were the same as above, but unfortunately the corrections to standard states have not been included. Consequently, we have recomputed the earlier results and the corrected values are presented in Tables $3-6$. The results obtained in this work are presented in Tables 2 and 7.

Table 3. The corrected values of the heats of combustion presented in References 1 and 2.

$m_{\text {corr. }}=0.99992 m$ in Ref. 1 and 2 (due to erroneous density of air in Refs. 1 and 2).

\begin{tabular}{|c|c|c|c|c|c|c|}
\hline $\begin{array}{l}m \\
g\end{array}$ & $\begin{array}{l}\Delta t \\
{ }^{\Delta} \mathrm{F}\end{array}$ & $\underset{\text { cal }}{\Delta E_{\text {ign }}}$ & $\Delta E_{\text {dec }}^{\mathrm{f}}\left(\mathrm{HNNO}_{3}\right)$ & $\begin{array}{c}\Delta E \Sigma \\
\text { cal }\end{array}$ & $\begin{array}{l}e^{\mathrm{f}}(\text { cont. }) \\
\mathrm{cal}^{\circ} \mathrm{F} \mathbf{F}\end{array}$ & $\begin{array}{c}-\Delta E_{\mathrm{c}}^{\circ} / \mathrm{M} \\
\mathrm{cal} / \mathrm{g}\end{array}$ \\
\hline \multicolumn{4}{|l|}{ 1,3-Dioxane } & \multicolumn{3}{|c|}{$\begin{array}{c}\mathrm{M}=88.107 \\
e^{\circ}(\text { calor })=1360\end{array}$} \\
\hline $\begin{array}{l}0.83286 \\
0.85108 \\
0.75528 \\
0.77660 \\
0.72935 \\
0.70472\end{array}$ & $\begin{array}{l}3.888 \\
\mathbf{3 . 9 6 8} \\
\mathbf{3 . 5 2 1} \\
\mathbf{3 . 6 2 3} \\
\mathbf{3 . 4 0 4} \\
\mathbf{3 . 2 9 3}\end{array}$ & $\begin{array}{r}14.28 \\
6.16 \\
5.60 \\
12.60 \\
9.80 \\
16.38\end{array}$ & $\begin{array}{l}18.25 \\
12.18 \\
20.10 \\
10.72 \\
14.34 \\
17.18 \\
-\Delta E_{c^{\circ}} / \mathrm{M}= \\
-\Delta E_{c}^{\circ}= \\
-\Delta H_{c}^{\circ}=\end{array}$ & $\begin{array}{c}2.36 \\
2.41 \\
2.08 \\
2.16 \\
1.99 \\
1.90 \\
6321.50 \\
56.97 \pm \\
57.56 \pm\end{array}$ & $\begin{array}{c}2.37 \\
2.39 \\
2.33 \\
2.35 \\
2.32 \\
2.30 \\
.07^{b} \mathrm{cal} \cdot{ }^{2} \\
2^{c} \mathrm{kcal} \cdot \mathrm{m} \\
3^{d} \mathrm{kcal} \cdot \mathrm{m}\end{array}$ & $\begin{array}{l}6319.44 \\
6328.95 \\
6315.64 \\
6324.28 \\
6323.80 \\
6316.86 \\
\\
\theta^{-1} \\
\theta^{-1}\end{array}$ \\
\hline \multicolumn{3}{|c|}{ 4-Methyl-1,3-dioxane } & \multicolumn{4}{|c|}{$\begin{array}{c}\mathrm{M}=102.134 \\
\left.e^{\circ}(\mathrm{col}) \mathrm{lor}\right)=1359.13\end{array}$} \\
\hline $\begin{array}{l}0.75753 \\
0.76854 \\
0.78065 \\
0.77184 \\
0.80268 \\
0.79898 \\
0.84793\end{array}$ & $\begin{array}{l}3.899 \\
3.955 \\
4.020 \\
3.976 \\
4.124 \\
4.127 \\
4.364\end{array}$ & $\begin{array}{r}15.68 \\
14.20 \\
11.62 \\
14.00 \\
7.84 \\
19.18 \\
17.92\end{array}$ & $\begin{array}{l}14.31 \\
16.85 \\
20.29 \\
19.30 \\
13.46 \\
20.27 \\
23.66 \\
-\Delta E_{\mathrm{c}}^{\circ} / \mathrm{M}= \\
-\Delta E_{\mathrm{c}}{ }^{\circ}= \\
-\Delta H_{\mathrm{c}}{ }^{\circ}=\end{array}$ & $\begin{array}{l}2.11 \\
2.14 \\
2.17 \\
2.15 \\
2.23 \\
2.22 \\
2.36 \\
=6966.3 \\
11.50 \pm \\
12.39 \pm\end{array}$ & $\begin{array}{c}2.34 \\
2.34 \\
2.34 \\
2.34 \\
2.36 \\
2.35 \\
2.37 \\
2.82^{a} \mathrm{cal} \\
5^{b} \mathrm{kcal} \cdot \mathrm{m} \\
9^{c} \mathrm{kcal} \cdot \mathrm{m}\end{array}$ & $\begin{array}{r}6965.10 \\
6963.10 \\
6967.31 \\
6967.45 \\
6965.73 \\
6980.35 \\
6955.35 \\
-1 \\
9^{-1} \\
9^{-1}\end{array}$ \\
\hline \multicolumn{3}{|c|}{ 2-Methyl-1,3-dioxane } & \multicolumn{4}{|c|}{ 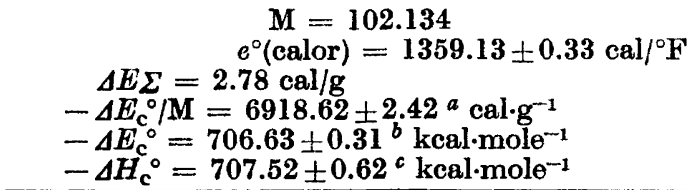 } \\
\hline
\end{tabular}

${ }^{a}$ Standard deviation of the mean. ${ }^{b}$ Over-all standard deviation. ${ }^{c}$ Twice the over-all standard deviation. 
Table 4. The corrected values of the heats of combustion presented in References 1 and 2. $m_{\text {corr. }}=0.99992 m$ in Refs. 1 and 2 (due to erroneous density of air in Refs. 1 and 2).

\begin{tabular}{|c|c|c|c|c|c|c|}
\hline $\begin{array}{c}m \\
\mathbf{g}\end{array}$ & $\underset{{ }^{\circ} \mathbf{F}}{\Delta t}$ & $\begin{array}{c}\Delta E_{\text {ign }} \\
\text { cal }\end{array}$ & $\underset{\text { cal }}{\Delta E_{\text {dec }}^{f}\left(\mathrm{HNO}_{8}\right)}$ & $\underset{c a l}{\Delta E \Sigma}$ & $\begin{array}{l}e^{f}(\text { cont.) } \\
\text { cal } /{ }^{\circ} F\end{array}$ & $\underset{\mathrm{cal} \cdot \mathrm{g}^{-1}}{-\Delta E_{\mathrm{c}} / \mathrm{M}}$ \\
\hline \multicolumn{4}{|c|}{ cis-2,4-Dimethyl-1,3-dioxane } & \multicolumn{3}{|c|}{$\begin{array}{l}\mathrm{M}=116.16 \\
e^{\circ}(\mathrm{calor})=1359.13 \pm 0.33 \mathrm{cal} /{ }^{\circ} \mathrm{F}\end{array}$} \\
\hline $\begin{array}{l}0.73554 \\
0.85248 \\
0.59999 \\
0.61380 \\
0.64725 \\
0.59147 \\
0.89662\end{array}$ & $\begin{array}{l}4.023 \\
4.667 \\
\mathbf{3 . 2 9 5} \\
\mathbf{3 . 3 7 2} \\
\mathbf{3 . 5 5 1} \\
\mathbf{3 . 2 5 1} \\
\mathbf{4 . 8 9 4}\end{array}$ & $\begin{array}{r}9.52 \\
6.58 \\
18.06 \\
14.00 \\
7.28 \\
17.50 \\
11.20\end{array}$ & $\begin{array}{l}10.97 \\
21.35 \\
13.97 \\
18.45 \\
21.59 \\
9.46 \\
14.08 \\
-\Delta E_{c}^{\circ} / \mathrm{M}= \\
-\Delta E_{c}^{\circ}=8 \\
-\Delta H_{c}^{\circ}=8\end{array}$ & $\begin{aligned} 2.11 \\
2.53 \\
1.61 \\
1.66 \\
1.78 \\
1.58 \\
2.70 \\
=7419 . \\
61.83 \pm \\
33.01 \pm\end{aligned}$ & $\begin{array}{c}2.35 \\
2.39 \\
2.27 \\
2.27 \\
2.28 \\
2.27 \\
2.43 \\
3^{3.85} \mathrm{cal} \\
0^{b} \mathrm{kcal} \cdot \mathrm{m} \\
c^{c} \mathrm{kcal} \cdot \mathrm{mo}\end{array}$ & $\begin{array}{r}7415.82 \\
7418.07 \\
7420.41 \\
7423.48 \\
7421.73 \\
7434.65 \\
7400.57 \\
-1 \\
-1\end{array}$ \\
\hline \multicolumn{3}{|c|}{ 4,5-Dimethyl-1,3-dioxane } & \multicolumn{4}{|c|}{$\begin{array}{c}\mathrm{M}=116.16 \\
e^{\circ}(\mathrm{calor})=1358.32 \pm 0.30 \mathrm{cal} /{ }^{\circ} \mathrm{F} \\
-\Delta E_{\Sigma}=2.71 \mathrm{cal} / \mathrm{g} \\
-\Delta E_{\mathrm{c}}^{\circ} / \mathrm{M}=744.19 \pm 0.95{ }^{a} \mathrm{cal} \cdot \mathrm{g}^{-1} \\
-\Delta E_{\mathrm{c}}{ }^{\circ}=865.08 \pm 0.24{ }^{b} \mathrm{kcal} \cdot \mathrm{mol}^{-1} \\
-\Delta H_{\mathrm{c}}{ }^{\circ}=866.26 \pm 0.48^{c} \mathrm{kcal} \cdot \mathrm{mole}^{-1}\end{array}$} \\
\hline \multicolumn{3}{|c|}{ 5,5-Dimethyl-1,3-dioxane } & \multicolumn{4}{|c|}{$\begin{array}{c}\mathrm{M}=116.16 \\
e^{\circ}(\text { calor })=1358.3\end{array}$} \\
\hline $\begin{array}{l}0.72841 \\
0.79990 \\
0.64222 \\
0.74003 \\
0.71510 \\
0.63121 \\
0.62530\end{array}$ & $\begin{array}{l}3.998 \\
4.398 \\
\mathbf{3 . 5 2 9} \\
4.061 \\
\mathbf{3 . 9 3 3} \\
\mathbf{3 . 4 6 6} \\
\mathbf{3 . 4 3 5}\end{array}$ & $\begin{array}{r}10.50 \\
20.16 \\
11.80 \\
12.88 \\
18.88 \\
18.76 \\
8.96\end{array}$ & $\begin{array}{c}18.76 \\
15.48 \\
18.87 \\
14.21 \\
19.25 \\
8.79 \\
19.78 \\
-\Delta E_{c}^{\circ} / \mathrm{M}= \\
-\Delta E_{\mathrm{c}}^{\circ}=8 \\
-\Delta H_{\mathrm{c}}{ }^{\circ}=8 \\
\end{array}$ & $\begin{array}{l}2.07 \\
2.33 \\
1.76 \\
2.11 \\
2.02 \\
1.73 \\
1.70 \\
7427 . \\
62.76 \pm \\
63.94 \pm\end{array}$ & $\begin{array}{c}2.33 \\
2.37 \\
2.29 \\
2.34 \\
2.32 \\
2.29 \\
2.28 \\
1.33 a \\
b^{b} \mathrm{kcal} \cdot \mathrm{m} \\
3^{b} \mathrm{kcal} \cdot \mathrm{m} \\
\end{array}$ & $\begin{array}{r}7425.14 \\
7433.86 \\
7425.90 \\
7427.32 \\
7430.10 \\
7423.19 \\
7425.59 \\
-1 \\
-1 \\
-1\end{array}$ \\
\hline
\end{tabular}

$a$ Standard deviation of the mean. ${ }^{b}$ Over-all standard deviation. ${ }^{c}$ Twice the over-all standard deviation.

The purities of the compounds were checked with Shandon Universal gas chromatograph fitted with a 6-foot long copper tube containing Silocel C 22 as solid support and didecyl phthalate as stationary phase and a flame ionization detector. The carrier gas was composed of $75 \%$ nitrogen and $25 \%$ hydrogen and its flow rate was about 100 $\mathrm{ml} / \mathrm{min}$. The column temperature was in the range $64-120^{\circ} \mathrm{C}$.

The final over-all precision of the $\Delta E_{\mathrm{c}}^{\circ}$ mean values was estimated following the scheme presented by Bjellerup ${ }^{11}$ with two modifications. The quantity $q_{5}$ was adopted from Månsson et al..$^{12}$ and our auxiliary material was gelatin and not an oil.

\section{RESULTS AND DISCUSSION}

The 1,3-dioxane ring exists mostly in the chair form (1), , 13,14 although some substituted derivatives may have stable flexible forms (2). ${ }^{13,14}$ It was recently estimated that the enthalpy difference between the chair and skew-

Acta Chem. Scand. 22 (1968) No. 8 
Table 5. The corrected values of the heats of combustion presented in References 1 and 2. $m_{\text {corr. }}=0.99992 m$ in Refs. 1 and 2 (due to erroneous density of air in Refs. 1 and 2).

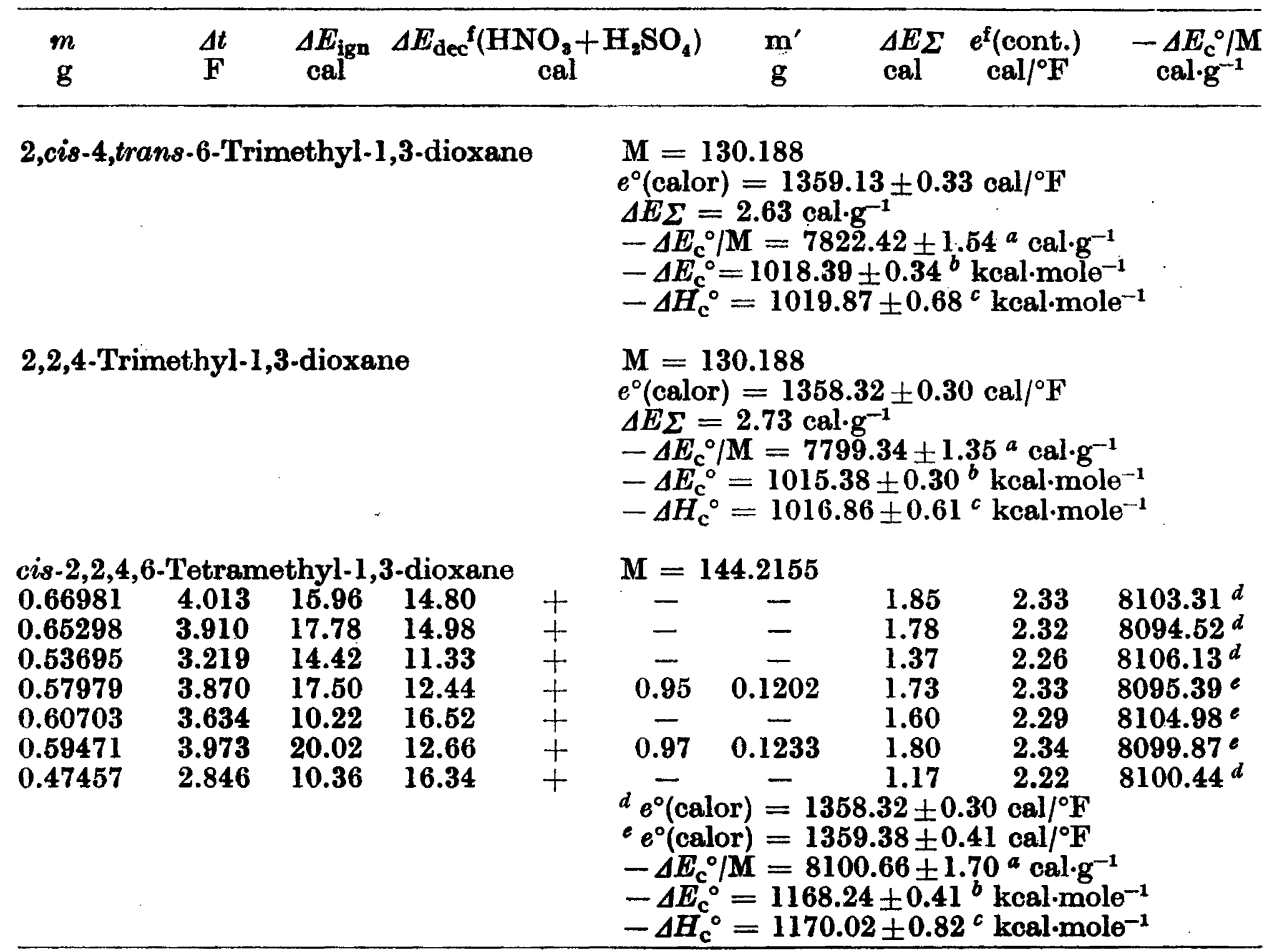

$a$ Standard deviation of the mean. ${ }^{b}$ Over-all standard deviation. ${ }^{c}$ Twice the over-all standard deviation. $\mathrm{m}^{\prime}$ is the mass of gelatin capsule.

boat forms of the 1,3-dioxane ring is $6.8 \pm 0.7 \mathrm{kcal} \cdot \mathrm{mole} \mathrm{e}^{-1}$ using the heats of formation presented by Pihlaja and Heikkilä.13,1,2 Now it is possible to make more accurate evaluation from this energy difference with the aid of the corrected heats of formation in Tables 3-6.

Group increments: The heat of formation of gaseous cyclohexane is -29.43 $\mathrm{kcal} \cdot \mathrm{mole}^{-1}$ at $25^{\circ} \mathrm{C}$. This value and the heat of formation of gaseous 1,3 dioxane, ${ }^{*}-83.42 \mathrm{kcal} \cdot \mathrm{mole}^{-1}$, can be used to estimate the increment to

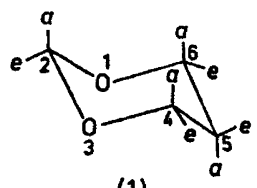

(1)

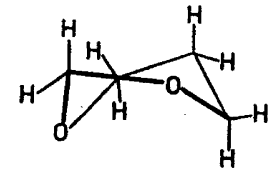

(2)

* $\Delta H_{\text {vap }}$ is taken from Ref. 1 . 
Table 6. The corrected value of the heat of combustion of trans-2,2,4,6-tetramethyl-1,3dioxane presented in Ref. 2.

\begin{tabular}{|c|c|c|c|c|c|c|c|c|c|}
\hline \multicolumn{10}{|c|}{$\begin{array}{l}m_{\text {corr. }}=0.99992 m \text { in Ref. } 2 \text { (due to erroneous density of air in Ref. } 2 \text { ). } \\
e^{\circ}(\text { calor })=1360.31 \pm 0.23 \mathrm{cal} /{ }^{\circ} \mathrm{F} \\
c e^{\circ} \text { (calor) }=1358.32 \pm 0.30 \mathrm{cal} / / \mathrm{F} \\
f e^{\circ} \text { (calor) }=1359.38 \pm 0.41 \mathrm{cal} /{ }^{\circ} \mathrm{F} \\
-\Delta e_{\mathrm{c}}^{\circ}(\mathrm{gel})=4522.37 \pm 2.86 \mathrm{cal} / \mathrm{g} \\
\mathrm{M}=144.2155\end{array}$} \\
\hline $\begin{array}{l}m \\
\mathrm{~g}\end{array}$ & $\begin{array}{l}\mathbf{m}^{\prime} \\
\mathrm{g}\end{array}$ & $\begin{array}{c}m^{\prime \prime} \\
\mathrm{g}\end{array}$ & ${ }^{\Delta t} \mathbf{F}$ & $\underset{\text { cal }}{\Delta E_{\text {ign }}}$ & $\mathrm{dec}_{\mathrm{fe}}^{\mathrm{f}}(\mathbf{H}]$ & $\begin{array}{l}\left.\mathrm{CNO}_{3}+\mathrm{H}_{2} \mathrm{SO}_{4}\right) \\
\text { cal }\end{array}$ & $\begin{array}{c}\Delta E \Sigma \\
\mathrm{cal}\end{array}$ & $\begin{array}{c}e^{f}(\text { cont. }) \\
\text { cal } /{ }^{\circ} \mathrm{F}\end{array}$ & $\begin{array}{c}-\Delta E_{\mathrm{c}}{ }^{\circ} / \mathbf{M} \\
\mathbf{c a l} \cdot \mathrm{g}^{-1}\end{array}$ \\
\hline $\begin{array}{l}0.54167 d \\
0.46304 \\
0.53687 \\
0.53567 \\
0.55456 \\
0.51752\end{array}$ & $\begin{array}{l}\overline{-} \\
0.1213 \\
0.1235 \\
0.1288 \\
0.1237\end{array}$ & $\begin{array}{l}0.03153 \\
0.04027 \\
0.04353 \\
0.04344 \\
0.04497 \\
0.04196\end{array}$ & $\begin{array}{l}\mathbf{3 . 4 4 1} \\
\mathbf{3 . 0 2 1} \\
\mathbf{3 . 8 9 1} \\
\mathbf{3 . 8 9 0} \\
\mathbf{4 . 0 2 8} \\
\mathbf{3 , 7 6 2}\end{array}$ & $\begin{array}{l}14.70 \\
16.38 \\
15.96 \\
17.92 \\
18.06 \\
10.78\end{array}$ & $\begin{array}{r}16.58 \\
6.16 \\
12.58 \\
12.88 \\
13.30 \\
12.36 \\
-\Delta E_{c}^{\circ} \\
-\Delta F_{c}^{\circ} \\
-\Delta H_{c}\end{array}$ & 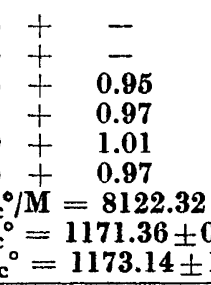 & $\begin{array}{r}1.48 \\
1.39 \\
1.97 \\
1.97 \\
2.05 \\
1.90 \\
2 \pm 3.1 \\
0.56^{b} \\
1^{c} .13^{c}\end{array}$ & $\begin{array}{c}2.27 \\
2.25 \\
2.30 \\
2.30 \\
2.31 \\
2.29 \\
1^{a} \mathrm{cal} \cdot \mathrm{cg}^{-1} \\
\mathrm{kcal} \cdot \mathrm{mole} \\
\mathrm{kcal} \cdot \mathrm{mole}\end{array}$ & $\begin{array}{l}8123.89 \\
8120.56 \\
8131.72 \\
8125.93 \\
8121.26 \\
8110.59 \\
\\
\theta^{-1} \\
\theta^{-1} \\
\end{array}$ \\
\hline
\end{tabular}

$a$ Standard deviation of the mean. ${ }^{b}$ Over-all standard deviation. ${ }^{c}$ Twice the over-all standard deviation. $m^{\prime \prime}$ is the mass of cis.2,2,4,6-dimethyl-1,3-dioxane present as impurity.

Table \%. The combustion data of 2,2-dimethyl- and 4,4,6-trimethyl-1,3-dioxanes.

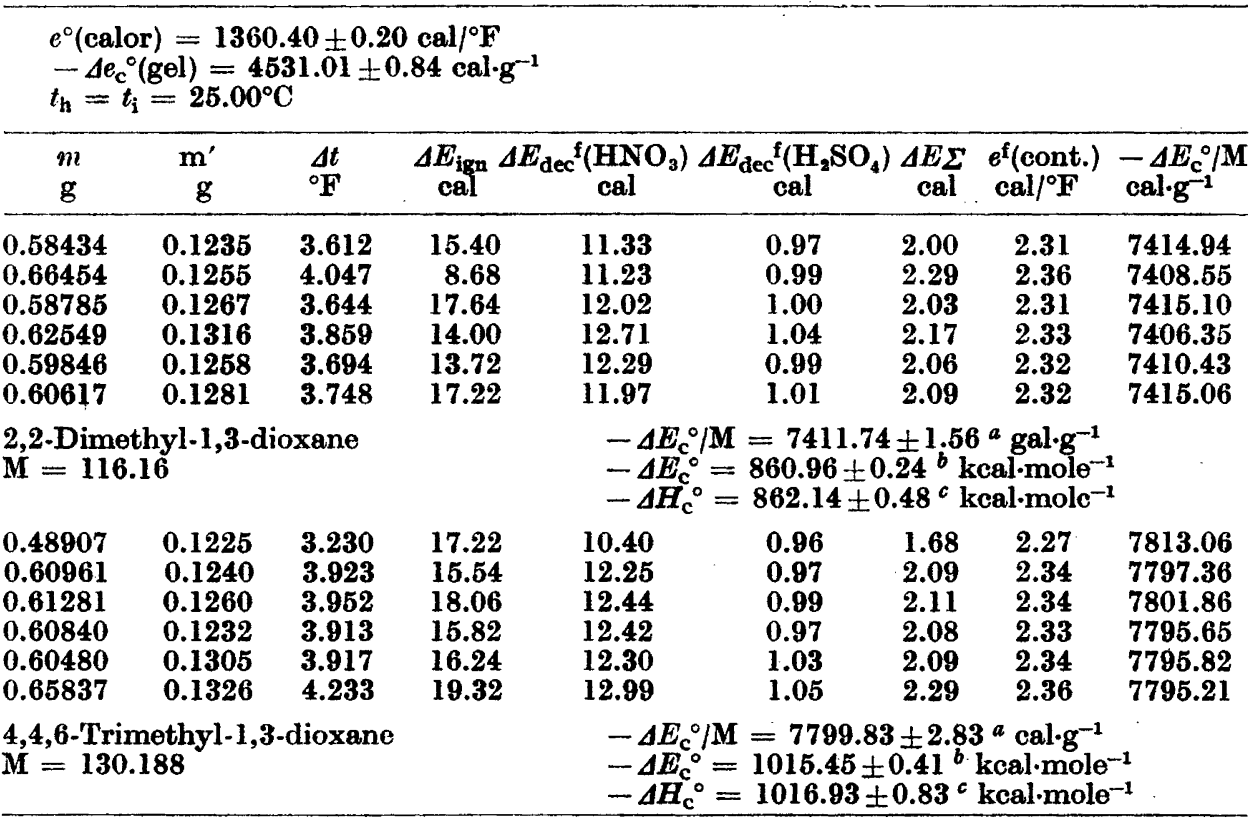

$a$ Standard deviation of the mean. ${ }^{b}$ Over-all standard deviation. ${ }^{c}$ Twice the over-all stand. ard deviation.

Acta Chem. Scand. 22 (1968) No. 8 
Table 8 . The standard heats of formation determined in this work or measured by other authors.

\begin{tabular}{|c|c|c|c|}
\hline Compound & Ref. & $\begin{array}{c}-\Delta H_{\mathrm{f}}^{\circ} \text { (liq.), } \\
\text { Obs. }\end{array}$ & $\begin{array}{l}\text { kcal.mole } \\
\text { Calc. }\end{array}$ \\
\hline 1,3-Dioxane (I) & 1 & $91.92 \pm 0.43$ & - \\
\hline 4-Methyl (II) & 1 & $99.44 \pm 0.69$ & 99.46 \\
\hline 2-Methyl (VI) & 1 & $104.32 \pm 0.62$ & 104.08 \\
\hline cis-2,4-Dimethyl (III) & l & $111.19 \pm 1.01$ & 111.62 \\
\hline 2,2-Dimethyl (V) & this work & $112.06+0.48$ & 112.17 \\
\hline 2,2,4-Trimethyl ( $(X)$ & 2 & $119.71 \pm 0.61$ & 119.71 \\
\hline 5,5.Dimethyl (VIII) & 1 & $110.26 \pm 0.53$ & 110.13 \\
\hline 2,cis-4,trans-6-Trimethyl (IX) & 1 & $116.70 \pm 0.68$ & 116.44 \\
\hline cis-2,2,4,6-Tetramethyl (XI) & 2 & $128.92 \pm 0.82$ & $128.92^{a}$ \\
\hline 4,5-Dimethyl (XIV) & l & $107.95 \pm 0.48$ & 108.02 \\
\hline trans-2,2,4,6-Tetramethyl (XIIB) & 2 & $125.79 \pm 1.13$ & \\
\hline cis-4,6-Dimethyl (IV) & this work & $113.48 \pm 0.57$ & $113.48^{a}$ \\
\hline trans-4,6-Dimethyl (VII) & this work & $110.56 \pm 0.43$ & 110.76 \\
\hline 4,4,6-Trimethyl (XIII) & this work & $119.64 \pm 0.83$ & 119.0 \\
\hline
\end{tabular}

a As these are the only acetonal and formal with the biased diequatorial system, the differences vanish automatically.

$\Delta H_{f}^{\circ}(\mathrm{g})$ resulting from the replacement of a $-\left(\mathrm{CH}_{2}\right)_{2}$-grouping in cyclohexane by an $-\mathrm{CH}_{2}-\mathrm{O}$-grouping. This increment is $-36.81 \pm 0.35 \mathrm{kcal} \cdot \mathrm{mole}^{-1}$ in good agreement with the values reported by Mansson et al. ${ }^{12}$ on the basis of the enthalpies of formation of gaseous trioxane and tetroxane. In connection with the recent investigation on aliphatic oxygen compounds ${ }^{15}$ it was observed that the derived bond-bond interaction scheme which suits well for aliphatic alcohols, ethers and acetals is less effective for some "oxanes". In a forthcoming paper a more detailed discussion of this discrepancy will be given. ${ }^{16}$

In the preceding papers ${ }^{1,2}$ some group increments to the heats of formation of gaseous 1,3-dioxanes at $25^{\circ} \mathrm{C}$ were presented. In this work group increments to the heats of formation of liquid 1,3-dioxanes were calculated in order to clarify their conformational energies in the liquid state.

The contributions of axial and equatorial methyl groups at the same position differ from each other since an axial methyl group at position 2, 4, or 6 interacts strongly with the axial hydrogen at the two other positions. An axial methyl group at position 5 leans outward, because the ring is flattened in the $\mathrm{C}_{4-5-6}$ region and as a result its distance from the sterically interacting ring atoms increases. ${ }^{14}$ Moreover, the axial methyl group at position 5 interacts only with the electron pairs of the oxygen atoms and the value of this interaction has been found to be about $0.84 \mathrm{kcal} \cdot \mathrm{mole}^{-1} \cdot 5,14,17$

From the studied compounds 1,3-dioxane (I), 2,2-dimethyl-1,3-dioxane (V), trans-4,6-dimethyl-1,3-dioxane (VII) and 5,5-dimethyl-1,3-dioxane (VIII) are equilibrium mixtures of two superposable and equally populated conformations, whereas cis-2,4-dimethyl-1,3-dioxane (III), cis-4,6-dimethyl-1,3-dioxane (IV), 4,4,6-trimethyl-1,3-dioxane (XIII), 2,cis-4,trans-6-trimethyl-1,3-dioxane 


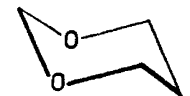

I<smiles>[R]C1([R])OCCCO1</smiles>

V<smiles></smiles>

IX

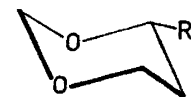

II<smiles>[R]C1OCCCO1</smiles>

VI<smiles>[R]C1CCOC([R])([R])O1</smiles>

$\mathrm{X}$<smiles>[R]C1CCOC([R])O1</smiles>

III

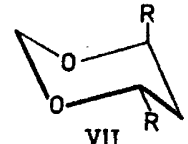

VII<smiles>[R]C1COC([R])([R])OC1[R]</smiles>

$\mathrm{XI}$

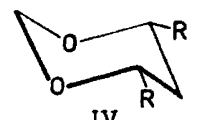

IV<smiles>[R4]C1CC([R])OC([R])C([R])OC([R])C([R])O1</smiles><smiles>[R]C1COCOC([R])([R])C1[R]</smiles><smiles>[R]C1COCOC([R])C([R])COC1[R]</smiles><smiles>[R]C1OCCOC([R])O1</smiles>
XVA<smiles>[R]C1CCC(OC=C)C([R])O1</smiles>

Fig. 1. The predominating conformations of the studied 1,3-dioxanes. ( $R$ is methyl).

(IX) and cis-2,2,4,6-tetramethyl-1,3-dioxane (XI) have only one biased conformation. 4-Methyl-1,3-dioxane (II), 2-methyl-1,3-dioxane (VI) and 2,2,4trimethyl-1,3-dioxane (X) exist predominantly in the equatorial conformation ${ }^{5,14}$ and 4,5-dimethyl-1,3-dioxane is a mixture of cis (ea) and trans (ee) configurations (ab. 1:2, XIV). ${ }^{18}$ trans-2,2,4,6-Tetramethyl-1,3-dioxane (XII) has the skew-boat form. ${ }^{13,14}$

In order to derive expressions for the compilation of the different group contributions the following abbreviations are used:

$x_{1}=$ the group increment to $\Delta H_{\mathrm{f}}^{\circ}$ (liq.) of an equatorial methyl group at positions 4 and 6 ,

$x_{2}=$ the group increment to $\Delta H_{1}^{\circ}$ (liq.) of an equatorial methyl group at position 2.

$x_{3}=$ the interaction enthalpy of an axial methyl group and an axial hydrogen atom at positions 2 and 4 (or vice versa),

$x_{4}=$ the interaction enthalpy of an axial methyl group and an axial hydrogen atom at positions 4 and 6 (or vice versa)=approximately the interaction enthalpy between two equatorial or equatorial and axial methyl groups at positions 4 and 5 (or vice versa).

Acta Chem. Scand. 22 (1968) No. 8 
$x_{5}=$ the group increment to $\Delta H_{\mathrm{f}}^{\circ}$ (liq.) of an equatorial methyl group at position 5 , and

$x_{6}=$ the stabilizing effect of the biased diequatorial system in cis-2,2,4,6tetramethyl-1,3-dioxane.

$H_{\mathrm{I}}, H_{\mathrm{II}}$ etc. are equal to the heats of formation of the corresponding 1,3 dioxanes.

From the heat of formation of 5,5-dimethyl-1,3-dioxane the value of $x_{5}$ is obtained directly, since

$$
2 x_{5}=H_{\mathrm{vII}}-H_{\mathrm{I}}-0.84=-110.26+91.08 \pm 0.96=-19.18 \pm 0.96
$$

and $x_{5}$ is $-9.59 \pm 0.48 \mathrm{kcal} \cdot \mathrm{mole}^{-1}$. The value, $0.84 \mathrm{kcal} \cdot \mathrm{mole}^{-1}$, in the above equation corresponds the interaction enthalpy of the axial methyl group at position $5^{5,14,17}$

Similarly we obtain

$$
\begin{aligned}
& x_{1}=H_{\mathrm{II}}-H_{\mathrm{I}} ; x_{2}=H_{\mathrm{vI}}-H_{1} ; x_{1}+x_{2}=H_{\mathrm{III}}-H_{\mathrm{I}} ; \\
& 2 x_{1}+x_{2}+x_{3}+x_{4}=H_{\mathrm{IX}}-H_{\mathrm{I}} ; x_{1}+2 x_{2}+2 x_{3}=H_{\mathrm{X}}-H_{\mathrm{I}} ; \\
& 2 x_{1}+2 x_{2}+2 x_{3}+x_{6}=H_{\mathrm{XI}}-H_{1} ; 2 x_{2}+2 x_{3}=H_{\mathrm{v}}-H_{\mathrm{I}}
\end{aligned}
$$

On the basis of the heats of formation of cis- and trans-4,6-dimethyl-1,3dioxanes the following expression is obtained

$$
x_{3}+x_{4}=H_{\mathrm{VII}}-H_{\mathrm{IV}}
$$

The heat of formation of the 1:2 mixture of cis- and trans-4,5-dimethyl-1,3dioxanes leads to equation

$$
x_{1}+x_{4}+x_{5}=H_{\mathrm{xvI}}-H_{1}-0.33 \times 0.84
$$

and after rearrangement and partial solution of the above expressions the following set of equations is derived

$$
\begin{aligned}
x_{1} & =-7.52 \\
x_{2} & =-12.40 \\
x_{1}+x_{2} & =-19.27 \\
2 x_{1}+x_{2}+x_{3}+x_{4} & =-24.78 \\
x_{1}+2 \quad x_{2}+2 x_{3} & =-27.79 \\
x_{3}+x_{4} & =2.92 \\
2 x_{1}+2 x_{2}+2 x_{3}+x_{6} & =-37.00 \\
x_{2}+x_{3} & =-9.59 \\
x_{1}+x_{4}+x_{5} & =-16.31
\end{aligned}
$$

The optimum group increments were then determined on an IBM 1130 computer using a linear regression program with a least squares fit. ${ }^{15}$ Table 8 lists the heats of formation of 1,3-dioxanes and Table 9 the compiled group increments and their standard errors.

From these group increments and the heat of formation of cis-4,6-dimethyl1,3-dioxane we can calculate the group contribution of an equatorial methyl group in this biased diequatorial system to be

$$
\begin{aligned}
H_{\mathrm{IV}}-H_{\mathrm{I}}-2 x_{1} & =(-113.48+91.92+15.08) / 2 \pm 0.70 \\
& =-3.24 \pm 0.70 \mathrm{kcal} \cdot \mathrm{mole}^{-1}
\end{aligned}
$$


Table 9. The compiled group increments to $\Delta H_{f}^{\circ}$ (liq.) of methyl-substituted 1,3-dioxanes.

\begin{tabular}{|c|c|c|c|}
\hline & Group & & Increment, kcal.mole ${ }^{-1}$ \\
\hline \multirow[t]{2}{*}{$\mathrm{CH}_{3}$} & $\begin{array}{l}4 e \text { (without 6-Me) } \\
2 e \\
\Delta(2 e-2 a) / 2 \\
2 a \\
4 a \text { (without 6-Me) } \\
\Delta(4 e-4 a)-x_{3} \\
5 e \\
4 e \text { (with } 6 e \text { ) in acetonals }\end{array}$ & $\begin{array}{l}x_{1} \\
x_{2} \\
x_{3} \\
x_{2}-2 x_{3} \\
x_{1}-x_{3}-x_{4} \\
x_{4} \\
x_{5} \\
x_{1}+\left(x_{6} / 2\right)\end{array}$ & $\begin{array}{l}-7.54 \pm 0.19 \\
-12.16 \pm 0.24 \\
+2.035 \pm 0.23 \\
-8.09 \pm 0.24 \\
=4.82 \pm 0.24 \\
+\quad 0.69 \pm 0.29 \\
=\mathbf{9 . 5 2} \pm 0.24 \\
-\mathbf{8 . 3 7} \pm \mathbf{0 . 4 2} \\
\end{array}$ \\
\hline & & & $\mathrm{RMS}^{a} 0.30 \mathrm{kcal} \cdot \mathrm{mole}^{-1}$ \\
\hline$\left(\mathrm{CH}_{3}\right)_{2}:$ & $\begin{array}{l}4 e \text { (with 6-Me) in formals } \\
4 e \text { (with } 6-\mathrm{Me} \text { ) in acetals } \\
5 a \\
4 a \text { (with } 6 e \text { ) in formals } \\
4 a \text { (with } 6 e \text { ) in acetals } \\
4 e, 4 a \\
4 e, 5 e \text { or } 4 a, 5 e \text { or } 4 e, 5 a\end{array}$ & $\begin{array}{l}\left(H_{\mathrm{IV}}-H_{\mathrm{I}}\right) / 2 \\
x_{\mathrm{s}}+0.84 \\
H_{\mathrm{VII}}-H_{\mathrm{I}}+10.78\end{array}$ & $\begin{array}{l}-10.78 \pm 0.50 \\
=7.54 \pm 0.19 \\
=8.68 \pm 0.30 \\
=7.86 \pm 0.46 \\
=\quad 4.82 \pm 0.24 \\
=0.7 b \\
+0.69 \pm 0.29\end{array}$ \\
\hline
\end{tabular}

${ }^{a}$ Root Mean Square deviation of each correlation. ${ }^{b}$ Calculated by the bond-bond interaction scheme of Pihlaja and Kankare..$^{16}$

greater than the usual value $-7.54 \pm 0.19 \mathrm{kcal} \cdot \mathrm{mole}^{-1}$. This may be due to the fact that the puckering of the 1,3-dioxane ring (as chair form) decreases in the order 4,6-diequatorially substituted formal $>4$.6-diequatorially substituted acetonal $>4$,6-diequatorially substituted acetal, since a single methyl substituent at position 2 flattens the ring appreciably. This conclusion is in good agreement with the results described in Table 9 which show that the group contribution of an equatorial methyl group at position 4 in 2, cis-4,trans6-trimethyl-1,3-dioxane does not differ significantly from the value $-7.54 \pm 0.19 \mathrm{kcal} \cdot \mathrm{mole}^{-1}$, whereas the value of this increment in cis-2,2,4,6tetramethyl-1,3-dioxane is

$$
x_{1}+x_{8} / 2=7.54+0.83 \pm 0.42=8.37 \pm 0.42 \mathrm{kcal} \cdot \mathrm{mole}^{-1} \text {. }
$$

By using the bond-bond interaction scheme described recently by Pihlaja and Kankare ${ }^{15}$ it is possible to evaluate the enthalpy change for the following reaction

$$
\text { IV }+ \text { II (axial conformer) - I }=X I I I
$$

in the gaseous state and the value $\Delta H=-0.7 \mathrm{kcal} \cdot \mathrm{mole}^{-1}$ is obtained.

When assuming that the enthalpy difference for the above reaction in the liquid state is approximately equal to that in the gaseous state the heat of formation of 4,4,6-trimethyl-1,3-dioxane can be estimated, since

$$
\begin{aligned}
H_{\mathrm{xur}} & =H_{\mathrm{IV}}+x_{1}+x_{3}+x_{4}-0.7 \\
& =-113.48-7.54+2.04+0.69-0.7 \\
& =-119.0 \mathrm{kcal} \cdot \mathrm{mole}^{-1}
\end{aligned}
$$

Acta Chem Scand. 22 (1968) No. 8 
in agreement with the experimentally obtained value $-119.64 \pm 0.83$ kcal.mole ${ }^{-1}$.

Conformational energies. Eliel and Knoeber ${ }^{14}$ recently obtained the value $138 \pm 6$ for the constant of the equilibrium between the cis and trans forms of 2,4-dimethyl-1,3-dioxane and hence $-\Delta G^{\circ}=2.92 \pm 0.02 \mathrm{kcal} \cdot \mathrm{mole}^{-1}$ for these isomers. cis-2,4-Dimethyl-1,3-dioxane exists in the biased diequatorial chair conformation, but trans-2,4-dimethyl-1,3-dioxane may exist in two conformations (XVA and XVB, Fig. 1) in which either the methyl group in position 2 or the methyl group in position 4 is axially orientated. The conformational energy of an axial methyl group in position 2 is equal to $2 x_{3}=4.07$ $\mathrm{kcal} \cdot \mathrm{mole}^{-1}$ (Tables 9 and 10) and that of an axial methyl group in position 4 equal to $2.92 \pm 0.50 \mathrm{kcal} \cdot \mathrm{mole}^{-1}$ (experimentally obtained value) or $2.72 \pm 0.52$ kcal.mole ${ }^{-1}$ (compiled value, Tables 9 and 10). Consequently, the difference in the stabilities of the conformers of trans-2,4-dimethyl-1,3-dioxane is about $1.15-1.35 \mathrm{kcal} \cdot \mathrm{mole}^{-1}$ and thus the proportion of the $a, e$ conformer is about $10 \%$. This result is in good agreement with the assumption of Eliel and Knoeber ${ }^{14}$ that the ratio XVB/XVA is in excess of 5:1 and quite possibly as high as 10:1.

Table 10. The conformational energies or interaction enthalpies of methyl groups at different positions in the 1,3-dioxane ring.

\begin{tabular}{|c|c|c|}
\hline $\begin{array}{l}\text { Orientation of the } \\
\text { methyl groups }\end{array}$ & $\begin{array}{l}\text { Conformational energy or interaction } \\
\text { enthalpy, kcal } \cdot \mathrm{mole}^{-1}\end{array}$ & Ref. \\
\hline $2 a$ & $2 x_{3}=4.07 \pm 0.46$ & This work \\
\hline $4 a$ & 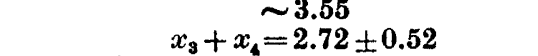 & $\begin{array}{l}14 \\
\text { This work }\end{array}$ \\
\hline $4 a$ & $H_{\mathrm{VII}}-H_{\mathrm{IV}}=\mathbf{2 . 9 2} \pm 0.50$ & This work \\
\hline $4 a$ & $2.92 \pm 0.02^{a}$ & 14 \\
\hline & $2.77 \pm 0.08 a$ & 14 \\
\hline & $2.73 \pm 0.02{ }^{a}$ & 14 \\
\hline & $2.87 \pm 0.04$ & 14 \\
\hline $5 a$ & 0.80 & 5,14 \\
\hline & & 14 \\
\hline & 0.89 国 & 17 \\
\hline $4 e, 5 e$ or $4 a, 5 e$ or $4 e, 5 a$ & $0.69 \pm 0.29$ & This work \\
\hline $\begin{array}{l}2 a, 4 a \\
4 a, 6 a\end{array}$ & $\begin{array}{l}\text { ab. } 8.9^{b} \\
\text { ab. } 3.0^{b}-4.0^{b}\end{array}$ & $\begin{array}{l}5 \\
\text { This work }\end{array}$ \\
\hline$\Delta H^{\circ}$ (skew-boat - chair) & & \\
\hline & $7.2_{6} \pm 0.7_{6}$ & \\
\hline & $6.8_{8} \pm 0.5_{8}$ & \\
\hline & Mean $7.1^{\circ} \pm 0.8^{\circ}$ & This work \\
\hline$\Delta S^{\circ}$ (skew-boat - chair) & $\begin{array}{l}6.8 \pm 0.7 \\
4.8 \pm 1.0^{c}\end{array}$ & This work \\
\hline & $3.9 \pm 0.5^{c}$ & 5,13 \\
\hline$\Delta G^{\circ}$ (skew-boat - chair) & $5.7 \pm 0.6$ & This work \\
\hline
\end{tabular}

a By equilibration of the cis and trans isomers of 2,4-dimethyl-, 2-ethyl-4-methyl-, 2-vinyl4-methyl- and 2-t-butyl-4-methyl-1,3-dioxanes, respectively. ${ }^{b}$ Estimations. ${ }^{c}$ cal $^{-d e g r} .^{-1} \mathrm{~mole}^{-1}$. 
From the above data we can calculate the value $-2.84 \mathrm{kcal} \cdot \mathrm{mole}-1$ for $\Delta G^{\circ}$ between cis- and trans-2,4-dimethyl-1,3-dioxanes which differs only slightly from the experimentally obtained result. ${ }^{14}$

The energy difference between the chair and skew-boat forms of the 1,3-dioxane ring. Using the scheme described earlier ${ }^{13}$ it is found that (a) assuming that 2,2-dimethyl-1,3-dioxane exists predominantly in the chair form ( $\geq 95 \%$ )

$-\Delta G^{\circ}{ }_{\mathrm{c} \leftrightarrow \mathrm{s}}=4.07+R T \ln 19=5.82 \pm 0.46 \mathrm{kcal} \cdot \mathrm{mole} \mathrm{e}^{-1}$

(b) the heats of formation of isomeric 2,2,4,6-tetramethyl-1,3-dioxanes differ by $3.13 \pm 0.97 \mathrm{kcal} \cdot \mathrm{mole}^{-1}$. cis-2,2,4,6-Tetramethyl-1,3-dioxane exists predominantly in the chair form ${ }^{13,14}$ (Fig. 1), whereas there is a strong interaction between the axial methyl groups at positions 2 and 6 in the chair form (XIIA) of trans-2,2,4,6-tetramethyl-1,3-dioxane. It was concluded earlier ${ }^{5,13,14}$ that the trans isomer has the skew-boat form (XIIB) in which, of the diaxial interactions in the chair form, only about $0.6 \mathrm{kcal} \cdot \mathrm{mole}{ }^{-1}$ remains. ${ }^{13}$ However, we think now that the interactions in trans-2,2,4,6-tetramethyl-1,3-dioxane are mainly due to the skew-boat form. ${ }^{10}$ Consequently

$$
\Delta H_{\mathrm{c} \leftrightarrow \mathrm{s}}=3.13+4.07 \pm 0.94=7.20 \pm 0.94 \mathrm{kcal} \cdot \mathrm{mole}^{-1} .
$$

(c) On the basis of the barrier to internal rotation $\left(2.72 \pm 0.14 \mathrm{kcal} \cdot \mathrm{mole}^{-1}\right)$ in dimethyl ether, ${ }^{19}$ the barrier to internal rotation in 1,3-dioxane is about $5.44 \pm 0.28 \mathrm{kcal} \cdot \mathrm{mole}^{-1}$.

If it is assumed that the third estimate (c) represents most likely a free energy difference, the excess entropy of the skew-boat form is (a) $4.6 \pm 1.0$ cal.degr ${ }^{-1} \mathrm{~mole}^{-1}$ and (c) $5.9 \pm 1.5$ cal.degr. ${ }^{-1} \mathrm{~mole}^{-1}$. An earlier estimation reports the value $3.9 \pm 0.5 \mathrm{cal} \cdot \mathrm{degr}^{-1} \mathrm{~mole}^{-1}$. Obviously the excess entropy ${ }^{5,13}$ of the skew-boat form of 1,3-dioxane ring is close to that of the corresponding form of cyclohexane (ab. 5 E.U.) and thus the mean of the above values, 4.8 \pm 1.0 E.U., seems to be valid to represent $-\Delta S^{\circ}{ }_{\mathrm{C} \leftrightarrow \mathrm{s}}$ for the 1,3-dioxane ring.

The heats of formation measured in this work or adopted by other investigators are collected in Table 8 and the compiled group increments in Table 9. The estimated conformational energies are presented in Table 10.

With the aid of the presented group increments it is possible to calculate the heats of formation of liquid methyl-substituted 1,3-dioxanes fairly accurately (Table 8). The values of the interaction energies of the axial methyl groups obtained in this work are generally in good agreement with those reported by Eliel and Knoeber ${ }^{14}$ and the small deviations may be due to experimental errors.

Acknowledgements. One of us (K.P.) wishes to thank Prof. Stig Sunner and Miss Margret Mansson from University of Lund, Sweden for their interest and for their help in computational problems. He (K.P.) also wishes to express his gratitude to Prof. Ernest L. Eliel, University of Notre Dame, Illinois, U.S.A., for many valuable comments. 


\section{REFERENCES}

1. Pihlaja, K. and Heikkilä, J. Acta Chem. Scand. 21 (1967) 2390.

2. Pihlaja, K. and Heikkilä, J. Acta Chem. Scand. 21 (1967) 2430.

3. Rondestvedt, Jr., C. S. J. Org. Chem. 26 (1961) 2247.

4. Aftalion, F., Lumbroso, D., Hellin, M. and Coussemant, F. Bull. Soc. Chim. France $19651950,1958$.

5. Pihlaja, K. Ann. Univ. Turkuensis Ser. A I (1967) No. 114. Thesis.

6. Böeseken, J. and Hermans, P. H. Ber. B 55 (1922) 3758.

7. Coops, J., Jessup, R. S. and Van Nes, K. In Experimental Thermochemistry, Vol. I, chapter 3, Interscience, New York 1956.

8. Hubbard, W. N., Scott, D. W. and Waddington, G. In Experimental Thermochemistry, Vol. I, chapter 5, Interscience, New York 1956.

9. Washburn, E. W. J. Res. Natl. Bur. Std. 10 (1933) 525.

10. Eliel, E. L. Private communication.

11. Bjellerup, L. Acta Chem. Scand. 15 (1961) 131.

12. Månsson, M., Morawetz, E., Nakase, Y. and Sunner, S. Acta Chem. Scand. In press.

13. Pihlaja, K. Acta Chem. Scand. 22 (1964) 716.

14. Eliel, E. L. and Knoeber, Sr., M. C. J. Am. Chem. Soc. 90 (1968) 3444.

15. Pihlaja, K. and Kankare, J. To be published.

16. Pihlaja, K. Unpublished results.

17. Riddell, F. G. and Robinson, J. T. Tetrahedron 23 (1967) 3417.

18. Pihlaja, K. and Äyräs, P. Private communication.

19. Kasai, P. H. and Myers, R. J. J. Chem. Phys. 30 (1959) 1096; Blukis, U., Kasai, P. H. and Myers, R. J. Ibid. 38 (1963) 2753.

Received November 17, 1967. 